\title{
Menisküs anatomisi
}

\author{
Meniscus anatomy
}

\author{
Celal Bozkurt, Mehmet Akif Altay
}

Harran Üniversitesi Tıp Fakültesi Ortopedi ve Travmatoloji Anabilim Dalı, Şanlıurfa

Menisküsler dizin lateral ve mediyalinde yer alan fibrokıkırdak özellikte, hilal kama şekilli yapılardır. Konkav femur eklem yüzeyi ve düz tibia plato yüzeyleri arasında eklemleşme imkanı sağlar, tibiofemoral eklem uyumluluğunu arttırarak diz eklemi aracılığıyla iletilen yüke bağlı olarak eklem kıkırdağı üzerinde oluşan stresi azaltır. Mediyal menisküs $C$ şekillidir ve mediyal tibial plato eklem temas alanının yaklaşık \%60'ını kaplar. Menisküs periferde eklem kapsülüne yapışır, koroner bağlar menisküsü tibiaya bağlar. Mediyal menisküs bazı anatomik özelliklere göre beş alt bölgede incelenebilir. Lateral menisküs daha yuvarlak, daha küçük, daha hareketli bir yapıya sahiptir ve tibia lateral plato eklem yüzünün \%60-80'ini kaplar (LaPrade, et al., 2014). Ön boynuz yapışma alanının yaklaşık \%63'lük kısmı ön çapraz bağ ile birleşmektedir. Arka çapraz bağ ve femur kondiline Humprey bağı (anterior meniskofemoral) ve Wrisberg bağı (posterior meniskofemoral) aracılığıyla yapışır. Yine popliteus tendonu ile de posterolateralde komşuluğu vardır. Menisküs anterior ve posterior kökleri, eklem kıkırdak yapısının korunmasında önemli yapılardır. Köklerde meydana gelen yaralanmalar menisküs yapısını ve biyomekaniğini bozmakta, bunun sonucunda menisküsün; dairesel yük dağılım mekanizması, şok emilimi, yük taşıma ve iletimi gibi özellikleri kaybolmaktadır. Çocuklarda kan damarları ve lenfatikler bir yaş dolana kadar menisküsün tamamında bulunur. On sekizinci ay civarında kanlanan menisküs bölgesi periferik \%2533'lük kısmına geriler. Erişkinlerde menisküs beslenmesi periferik bölgede kan damarlarıla, merkezi bölgede ise sinoviyal sıvıdan diffüzyon yoluyla olur. Menisküs periferik 2/3'lük kısmında ve boynuzlarda serbest sinir uçları ve Ruffini, Paccini ve Golgi tendon organı olmak üzere üç farklı mekanoreseptör bulunur. İç 1/3'lük kısımda innervasyon bulunmaz.

Anahtar sözcükler: menisküs; anterior-posterior kök; menisküs damarlanması; menisküs innervasyonu
The menisci are crescent shaped wedges of fibrocartilage located on the medial and lateral aspects of the knee. They create a suitable joint surface between concave femoral condyles and flat tibial plateaus. They decrease the stress on knee joint cartilage by increasing the joint surface area. Medial meniscus is $C$ shaped and constitute $60 \%$ of joint contact area on medial tibial plateau. Peripherally it is attached to the joint capsule via coronary ligaments. It is studied under five distinct areas according to some anatomical features. Lateral meniscus is more circular, mobile and smaller than medial meniscus. It covers $60-80 \%$ of lateral tibial plateau (LaPrade, et al., 2014). About $63 \%$ of anterior root blends with anterior cruciate ligament. Anterior meniscofemoral (Wrisberg) and posterior meniscofemoral (Humprey) ligaments exist between posterior cruciate ligament and femoral condyle. Lateral meniscus is contiguous to popliteus muscle tendon posterolaterally. Anterior and posterior roots of menisci are important for protecting the cartilage structure. Injuries of the roots disrupt the biomechanics and structure of the menisci. Consequently, circumferential load distribution mechanism, load transfer-transport, and shock absorption properties are lost. In childhood, vascular structures and lymphatics are found in the whole menisci. By the age 18 months, vessels are present only peripheral $25-33 \%$ of the menisci. In adults menisci nutrition is provided by vessels peripherally and by synovial fluids centrally. In the peripheric $2 / 3$ of the menisci there are free nerve endings, three different mechanoreceptors (Ruffini, Paccini and Golgi tendon organ). There is no innervation in the central $1 / 3$ of the menisci.

Key words: meniscus; anterior-posterior root; meniscus vasculature; meniscal innervation

- İletişim adresi: Doç. Dr. Mehmet Akif Altay, Harran Üniversitesi Tıp Fakültesi, Ortopedi ve Travmatoloji Anabilim Dalı, Şanlıurfa Tel: 0505 - 4827338 e-posta: maltay63@yahoo.com

- Geliș tarihi: 1 Mart $2018 \quad$ Kabul tarihi: 1 Mart 2018 
M enisküs ilk olarak artık organ olarak tanımlanmış bir yapıdır. ${ }^{[1]}$ Sonraki yıllarda, menisküsün diz eklem fonksiyonları için hayati önemde olduğu anlaşılmıştır. ${ }^{[2]}$ Menisküslerin en önemli görevi, tibiofemoral eklem uyumluluğunu arttırarak, diz eklemi aracılığıyla iletilen yüke bağlı olarak eklem kıkırdağı üzerinde oluşan stresi azaltmaktır. ${ }^{[3]}$ Ayrıca; şok emilimi, stabilite, lubrikasyon, beslenme ve propriyosepsiyon gibi ikincil görevleri de mevcuttur. ${ }^{[3]}$ Latince 'meniskos' 'hilal' kelimesinden gelmektedir. ${ }^{[4]}$

Üçyüz milyon yıl öncesindeki tetrapodlarda menisküs benzeri yapılar olduğu bildirilmektedir. Hominidlerde 1,3 milyon yıl öncesinde ilk olarak günümüzdeki patellofemoral eklemin geliştiği ve bipedal yürümenin başladığı bildirilmektedir. ${ }^{[5]}$ Tardieu, canlıların gelişim basamaklarında ara sıra olan bipedal yürüyüşsten sürekli bipedal yürüyüşe geçişi araştırmış ve tüm primatların morfolojik olarak benzer mediyal menisküse sahip olduğunu, lateral menisküsün ise farklılıklar gösterdiğini bildirmiştir. ${ }^{[6]}$ Homo sapiens'lere özgü lateral menisküsün ön ve arka olarak iki ayrı insersiyosu olduğunu ve bu yapının da yürüyüş esnasında diz ekleminde duruş ve salınım fazında tam ekstansiyonda bipedal yürüyüşe imkan verdiğini belirtmiştir. ${ }^{[6]}$

Menisküsler, dizin lateral ve mediyalinde yer alan fibrokıkırdak özellikte, hilal kama şekilli yapılardır; konkav femur eklem yüzeyi ve düz tibia plato yüzeyleri arasında eklemleşme olanağı sağlar, üçgen kesitlidir ve tibial platonun yaklaşık 2/3'ünü kaplar. ${ }^{[7,8]}$ Menisküs kökleri, menisküsleri subkondral kemiğe tespit eden ligamentöz yapılardır; bunlar, makaslama ve gerilme güçlerini yumuşak dokudan kemiğe transfer eder. ${ }^{[8]}$

\section{EMBRIYOLOJi VE GELIŞiM}

Menisküsler, eklem kapsülünü çevreleyen mezenkimal dokunun orta tabakasının yoğunlaşmasıyla oluşur ve sekizinci ile onuncu hafta arasında karakteristik şeklini alır. ${ }^{[9]}$ Gelişmekte olan menisküsün bütün bölümlerinde çok sayıda hücre ve damarlanma görülür. ${ }^{[10]}$ Çocuklarda, kan damarları ve lenfatikler bir yaş dolana kadar menisküsün tamamında bulunur. Çocuk yürümeye başlayıp menisküslere yük binmeye başladıktan sonra, 18 ay civarında kanlanan menisküs bölgesi periferik \%25-33'lük kısmına geriler, kollajen miktarı artar, hücre sayısı azalır. Yüklenme ve eklem hareketleri kollajen liflerinin dairesel yönelimini belirler.[10,11] Merkezdeki fibrokıkırdak bölge avasküler kalır. Tibia platosu mediyalde ve lateralde fetal dönemden erişkin döneme kadar, menisküsler tarafından değişken oranlarda kaplanır; bu oranlar, lateralde \%75-93, mediyalde ise \%51-74'tür. ${ }^{[10]}$

\section{BIYOKIMYASAL VE HÜCRESEL IÇERIK}

Tüm ağırlığının \%72'si sudur. Geri kalan \%28'inin içeriği çoğunlukla ekstrasellüler matriks (ESM) ve hücrelerden oluşan organik maddelerdir. Bu organik maddelerin \%75'ini kollajen oluştururken, \%17'sini glikozaminoglikanlar, \%2'sini DNA, \%1'inden azını adhezyon glikoproteinleri ve elastin oluşturur. ${ }^{[12]} \mathrm{Bu}$ oranlar, yaş, yaralanma durumu ve diğer patolojilere bağlı olarak farklııklar gösterebilir.

Menisküslerdeki temel lifler bileşik kollajendir; çok düşük oranlarda $(\% 0,6)$ elastin de içerir. Menisküslerde elastinin biyokimyasal ve fonksiyonel işlevi henüz aydınlatılamamıştır. Kollajen içeriği menisküs bölgesine göre değişiklik gösterir. Periferik bölgede, kollajen kuru ağırlığın \%80'ini oluşturur. Büyük oranda Tip 1 kollajendir, diğer tipler (Tip 2, 3, 4, 6 ve 18) \%1'den az oranda bulunur. Santral bölgede ise kuru ağırlığın \%70'ini kollajen oluşturur. Bu bölgedeki kollajenin \%60'। Tip 2, \%40'। Tip 1 kollajendir. ${ }^{[13,14]}$

ESM temel bileşenlerinden birisi de proteoglikanlardır. Proteoglikanlar da bölgesel olarak dağılım gösterir. Santral 2/3'lük kısım periferik 1/3'lük kısma göre daha fazla proteoglikan içerir. Proteoglikanların görevi menisküsün su içeriğini sağlamaktır. ${ }^{[12]}$ Yüklenme ile birlikte sıvı eklem aralığına geçer, yüklenme kalktığında ise tekrar menisküs içerisine girer. Bu mekanizma, hem fibrokondrositlerin beslenmesini hem de eklem lubrikasyonunu sağlar. ${ }^{[15]}$

Adhezyon glikoproteinleri de önemli ESM proteinlerinden birisidir. Bunlar, hücreler ve diğer ESM proteinleri arasında bağlantı kurar. Menisküste yer alan başlıca adhezyon glikoproteinleri; fibronektin, trombospondin ve kollajen Tip 6'dır. ${ }^{[14]}$

Menisküs içerisindeki hücrelerin sınıflandırılması netleşmemiştir. Santraldeki beyaz bölgede fibrokondrosit veya kondrosite benzeyen yuvarlak hücreler bulunur. Periferdeki kırmızı bölgede ise fibroblast olarak tanımlanan iğsi hücreler bulunur. ${ }^{[16]}$ Yüzeyel bölgede üçüncü bir hücre çeşidi daha tanımlanmıştır. Düz iğsi yapıda ve hücresel uzantıları olmayan bu hücrelerin, özel progenitör hücreler olabileceği düşünülmektedir (Şekil 1). ${ }^{[17]}$

\section{GENEL ANATOMi}

Menisküsler dizin lateral ve mediyalinde yer alan fibrokıkırdak yapıda, hilal şekilli, üçgen kesitli yapılardır. Konkav femur eklem yüzeyi ve düz tibia plato yüzeyleri arasında eklemleşme olanağı sağlar. Tibial platonun yaklaşık 2/3'ünü kaplar. ${ }^{[7,8]}$ Menisküsler tibiaya koroner (meniskotibial) bağlar ile bağlanır. Koroner bağlar kapsüler liflerden oluşur; proksimalde meniskülerin 


\section{Kırmızı-kırmızı bölge}

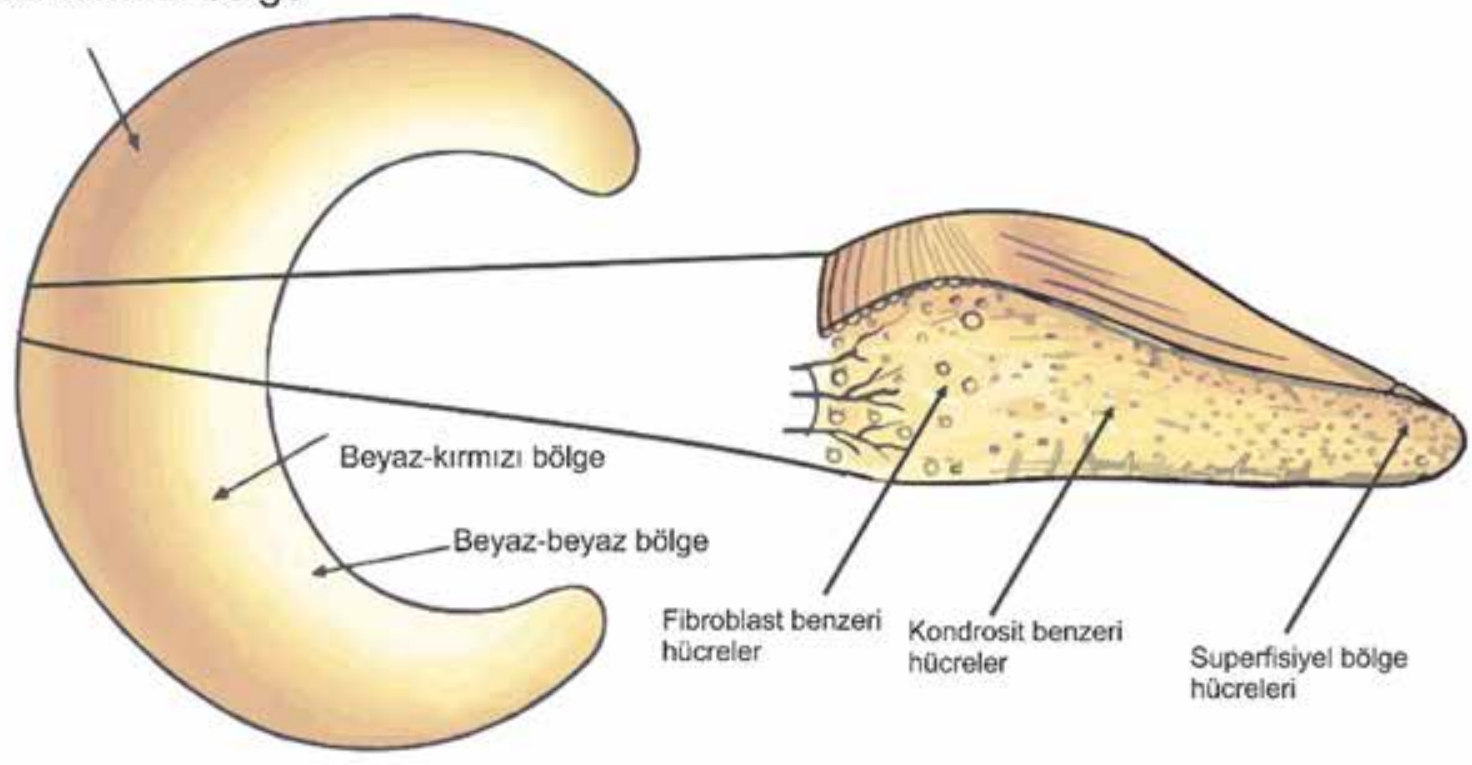

Şekil 1. Menisküs ve menisküs kesiti. Periferik bölgede fibroblast benzeri hücreler, santralde kondrosit benzeri hücreler ve yüzeyde süperfisiyel hücreler bulunur.

dış kenarlarına, distalde ise tibia kondillerine yapışır. Koroner bağlar tibia kondillerine eklem yüzeyinin birkaç $\mathrm{mm}$ altında yapışır ve bu bölgede sinoviyal boşluk oluşturur. ${ }^{[18]}$ Menisküs kökleri menisküsleri subkondral kemiğe tespit eden ligamentöz yapılardır; makaslama ve gerilme güçlerini yumuşak dokudan kemiğe transfer eder. ${ }^{[8]}$

\section{MEDIYAL MENISKÜS}

Mediyal menisküs $C$ şekillidir ve mediyal tibial plato eklem temas alanının yaklaşık \%60'ını kaplar. ${ }^{[10]}$ Arka boynuzu ön boynuza göre daha geniştir; arkadan öne doğru giderek küçülür ve ön-arka çapı mediyal lateral çapından daha büyüktür. Menisküs periferde eklem kapsülüne yapışır, koroner bağlar menisküsü tibiaya bağlar (Şekil 2). ${ }^{[19]}$ Mediyal menisküs bazı anatomik özelliklere göre beş bölgeye ayrılır; anterior kök bölgesi (1. Bölge), anteromediyal bölge (2. Bölge, 2a, 2b), mediyal bölge (3. Bölge), posterior bölge (4. Bölge), posterior kök bölgesi (5. Bölge) (Şekil 3). ${ }^{[20]}$

\section{Birinci Bölge-Anterior Kök}

Mediyal menisküs, anteriorda tibiaya yapıştığı bölgeye göre dört tipe ayrılmıştır. Birinci tip ve en sık olanında tibia platodaki düz interkondiller bölge, ikinci tipte daha mediyalde tibia eklem yüzeyine yakın bölge, üçüncü tipte daha anteriorda tibiadan aşağıya doğru uzanan bölge yapışma bölgesidir. Dördüncü tipte ise solid bir yapışma bölgesi yoktur ve sadece koroner lifler ile menisküs stabilitesi sağlanır. ${ }^{[21]}$

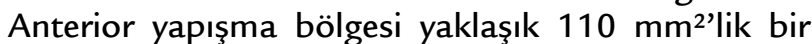
alandır. Bu alanın \%50'si santral lifler, \%50'si de destek liflerden oluşur. ${ }^{[22]}$

\section{Íkinci Bölge - Anteromediyal Bölge}

Anterior kök bölgesinden başlar ve mediyal kollateral bağ ön sınırına kadar uzanır. $2 a$ ve $2 b$ olmak üzere iki alt bölge içerir. 2a anterior kök bölgesinden transvers bağa kadar devam eder. $2 b$ ise transvers bağdan başlayıp mediyal kollateral bağ ön sınırına kadar uzanır. Mediyal menisküs 2a, 2b, 3 ve 4 . bölgeler tibiaya yalnızca meniskotibial bağlar (koroner bağ) ile bağlanır. ${ }^{[21]} 2 \mathrm{a}$ bölgesinde mediyal menisküs superiorunun çevre dokularla bağlantısı yoktur, $2 b$ bölgesinde ise sinoviyal doku ile bağlantı yapar. ${ }^{[20]}$

\section{Üçüncü Bölge - Mediyal Bölge}

Mediyal kollateral bağ bölgesidir. İnferior bölgesi tibiaya koroner bağlar ile, superiorda ise eklem kapsülüne bağlanır; periferde eklem kapsülüne tam bağlantı gösteren tek menisküs bölgesidir. Eklem kapsül komşuluğunda ise mediyal kollateral bağ bulunur (Şekil 4). ${ }^{[20]}$ 


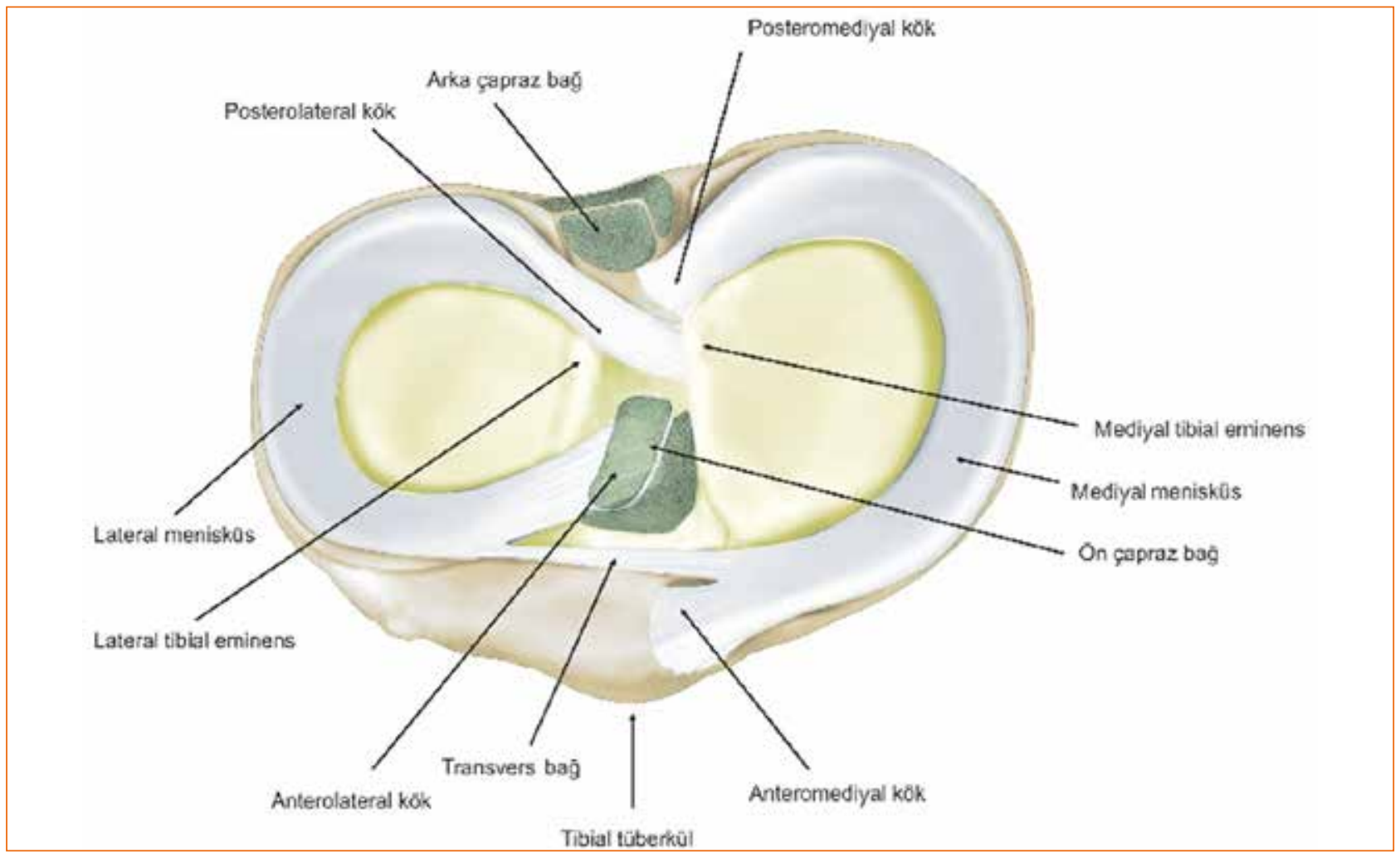

Şekil 2. Mediyal ve lateral menisküs tibial plato yerleşimi. Lateral menisküs anterior kök ve ön çapraz bağ tibial yapışma bölgesi kesişmektedir.

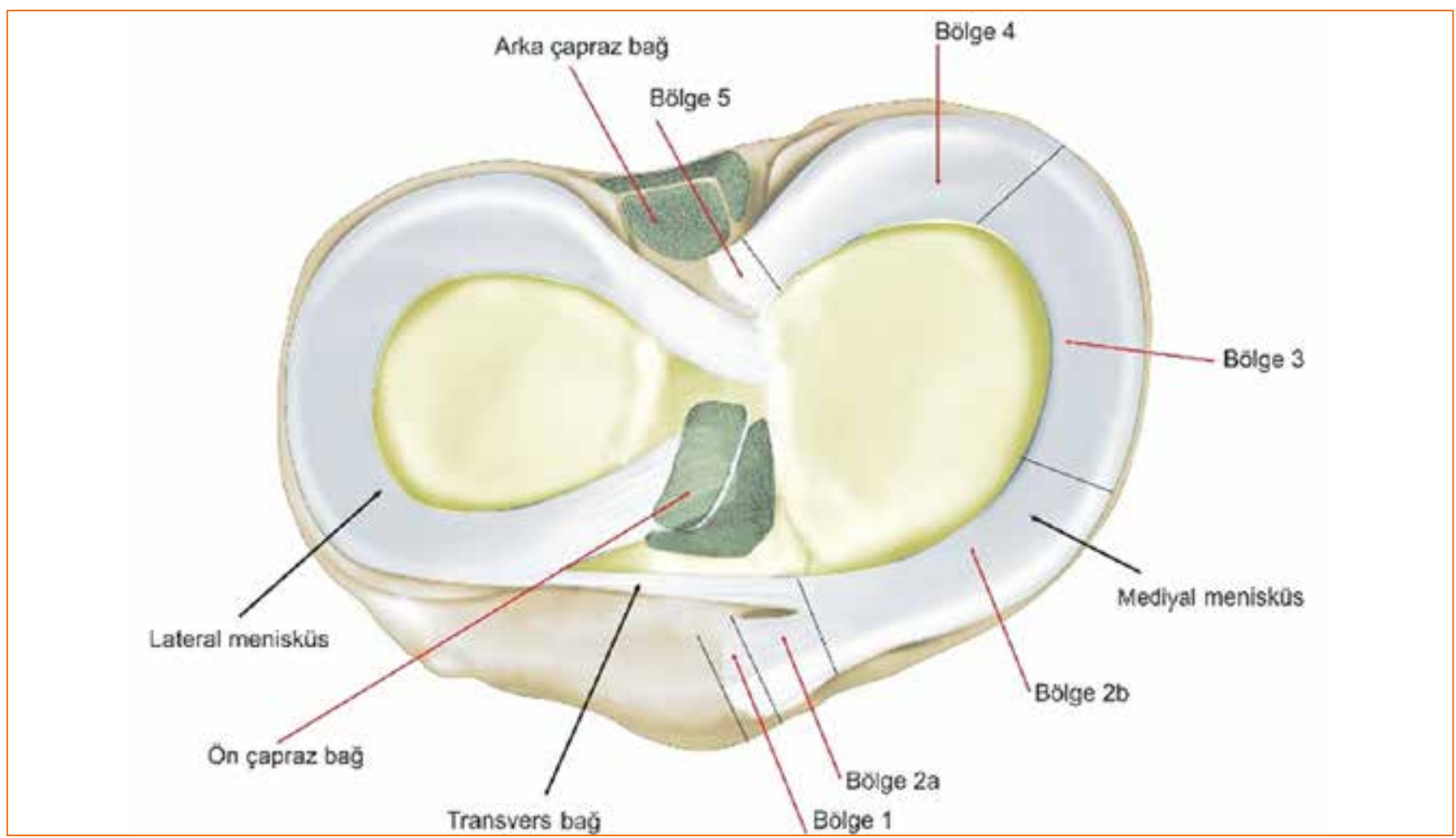

Şekil 3. Mediyal menisküs beş ayrı alt bölge altında incelenebilir. Birinci bölge anterior kök bölgesi, íkinci bölge anterior kök bölgesinden mediyal kollateral bağ komşuluğuna kadar olan bölge. İkinci bölge kök kısmından transevers bağa kadar 2a, transvers bağdan mediyal kollateral bağa kadar $2 b$ olarak ayrılır. Üçüncü bölge mediyal kollateral bağ komşuluğundaki bölge. Dördüncü bölge mediyal kollateral bağdan posterior köke uzanan bölge. Beşinci bölge posterior kök bölgesi. ${ }^{[19]}$ 


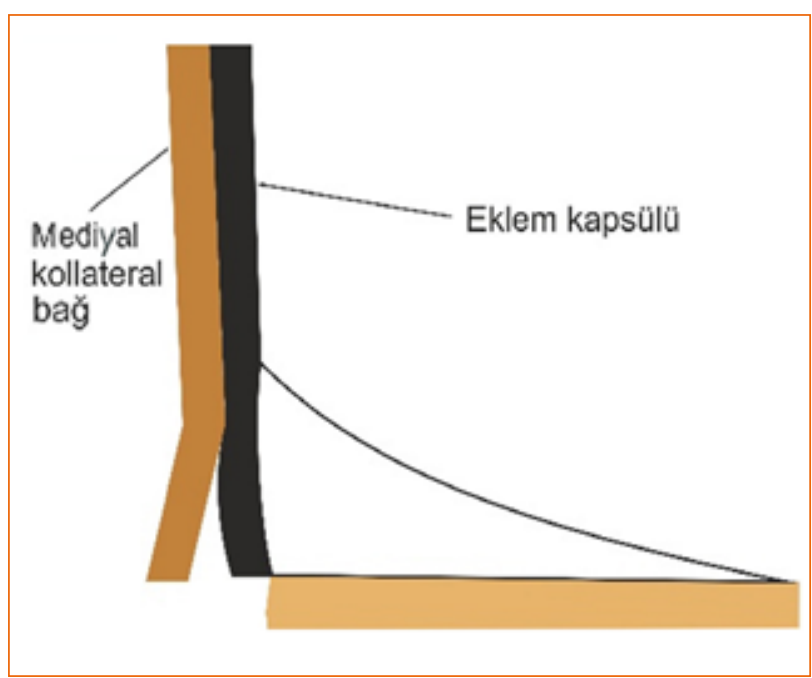

Şekil 4. Menisküs periferde eklem kapsülüne bağlanır, eklem kapsülünün ise mediyal kollateral bağ ile komşuluğu mevcuttur.

\section{Dördüncü Bölge - Posterior Boynuz}

$\mathrm{Bu}$ bölgede superiorda kapsülle bağlantı yoktur. Inferiorda koroner bağlarla tibiaya eklem yüzeyinin 7-10 mm distalinden bağlanır. ${ }^{[20]}$ Posteriorda eklem kapsülü ve menisküs posterioru arasında kalan bu bölge posterior femoral boşluk (reses) olarak tanımlanır. ${ }^{[23]}$

\section{Beşinci Bölge - Posterior Kök}

Mediyal menisküs posterior kök mediyal tibial eminensiya apeksinin posteriorunda ve lateralinde, arka çapraz bağ (AÇB) tibial yapışma bölgesinin anteromediyalinde, lateral menisküs arka boynuz yapışma yerinin posteriorunda yer alır (Şekil 2). ${ }^{24]}$

Ön ve arka kökleri içine alan birinci ve beşinci bölge anatomileri özelllikle menisküs transplantasyon cerrahisinde önemlidir; tamirlerinde ise stabiliteyi sağlamak için transosseöz katı tespit yapılmalıdır. 2a bölgesinde meniskotibial tutunmayı sağlamak için inferior vertikal dikiş atılmalıdır (superiorda tutunma yok, sadece inferiorda tibiaya koroner bağlar ile tutunum vardır). 2b bölgesinde superiordaki bağlantı bölgeleri de göz önünde bulundurulmalıdır. ${ }^{[20]}$ Üç̧üncü bölgede ise anatomik onarım için meniskotibial ve meniskofemoral-meniskokapsüler bağlar restore edilmelidir. Bu bölgede mediyal kollateral bağ ile olan yakın komşuluk açısından dikkatli olunmalıdır. Dördüncü bölgede atılacak dikişlerin posterior femoral boşluğu kapatarak diz hareketlerini kısıtlamaması açısından dikkatli olunmalıdır. ${ }^{[20]}$

\section{LATERAL MENISKÜS}

Lateral menisküs daha yuvarlak, daha küçük ve daha hareketli bir yapıya sahiptir. Mediyal menisküse göre daha büyük oranda bir alanı, lateral tibia plato eklem yüzünün \%60-80'ini kaplar. ${ }^{[10]}$ Lateral menisküs ön boynuz yapışma yeri ön çapraz bağ (ÖÇB) anterolateralinde, lateral tibial eminensiya apeksinin anteromediyalinde bulunur. ${ }^{[22]}$ Lateral menisküs ön boynuz yapışma alanının yaklaşık \%63'lük kısmı ÖÇB ile birleşmektedir. ${ }^{[22]}$ Lateral menisküs arka boynuz yapışma yeri lateral tibial eminensiya apeksinin posteromediyalinde, AÇB tibial yapışma bölgesinin anteriorunda ve mediyal menisküs arka boynuz yapışma bölgesinin anterolateralinde bulunur. Ana liflerinin yanı sıra bazı lifleri mediyal tibial eminensiya posterolateraline yapışır. ${ }^{[24]}$ Ayrıca AÇB ve femur kondiline Humprey bağı (anterior meniskofemoral) ve Wrisberg bağı (posterior meniskofemoral) aracılığıyla yapışır. Yine popliteus tendonu ile de posterolateralde komşuluğu vardır (Şekil 2, Şekil 5). ${ }^{[25]}$

\section{MEDIYAL VE LATERAL MENISKÜS ARASI BAĞLANTILAR}

Mediyal ve lateral menisküsler arasında dört farklı bağ mevcuttur. ${ }^{[26]}$ Transvers bağ (anterior intermeniskal bağ) \%60-94 dizde bulunur. Posterior intermeniskal bağ ise \%1-4 dizde bulunur. Mediyal oblik intermeniskal bağ \%1 dizde bulunur, mediyal menisküs anterior kök merkezinden geçer ve oblik bir şekilde lateral menisküs arka boynuz superioruna doğru uzanır. Lateral oblik intermeniskal bağ ise \%4 dizde bulunur, lateral menisküs anterior boynuzdan başlar ve mediyal menisküs arka boynuz superioruna yapışır. ${ }^{[21,27]}$

\section{MENISKÜS KÖK ANATOMISi}

Menisküs anterior ve posterior köklerinin eklem kıkırdak yapısının korunmasındaki önemi, yapılan çalışmalarda gösterilmiştir. Marzo ve ark., yaptıkları çalışmada mediyal menisküs arka kök yaralanmasının fonksiyonel sonuçlarının total menisektomiye denk olduğunu göstermişlerdir. ${ }^{[28,29]}$ Menisküs köklerinde meydana gelen yaralanmalar menisküs yapısını ve biyomekaniğini bozmakta, bunun sonucunda menisküsün dairesel yük dağılım mekanizması, şok emilimi, yük taşıma ve iletimi gibi özellikleri kaybolmaktadır. Sonuç olarak; menisküste taşma, eklem temas alanında azalma, eklem streslerinde artış ve hızlanmış osteoartrit süreci görülmektedir. ${ }^{[29]}$ Bu bölgelerde görülen yaralanmalar sonrasında menisküs köklerinin stabil ve anatomik bir şekilde onarılması, bozulan menisküs fonksiyonlarının düzeltilmesinde 


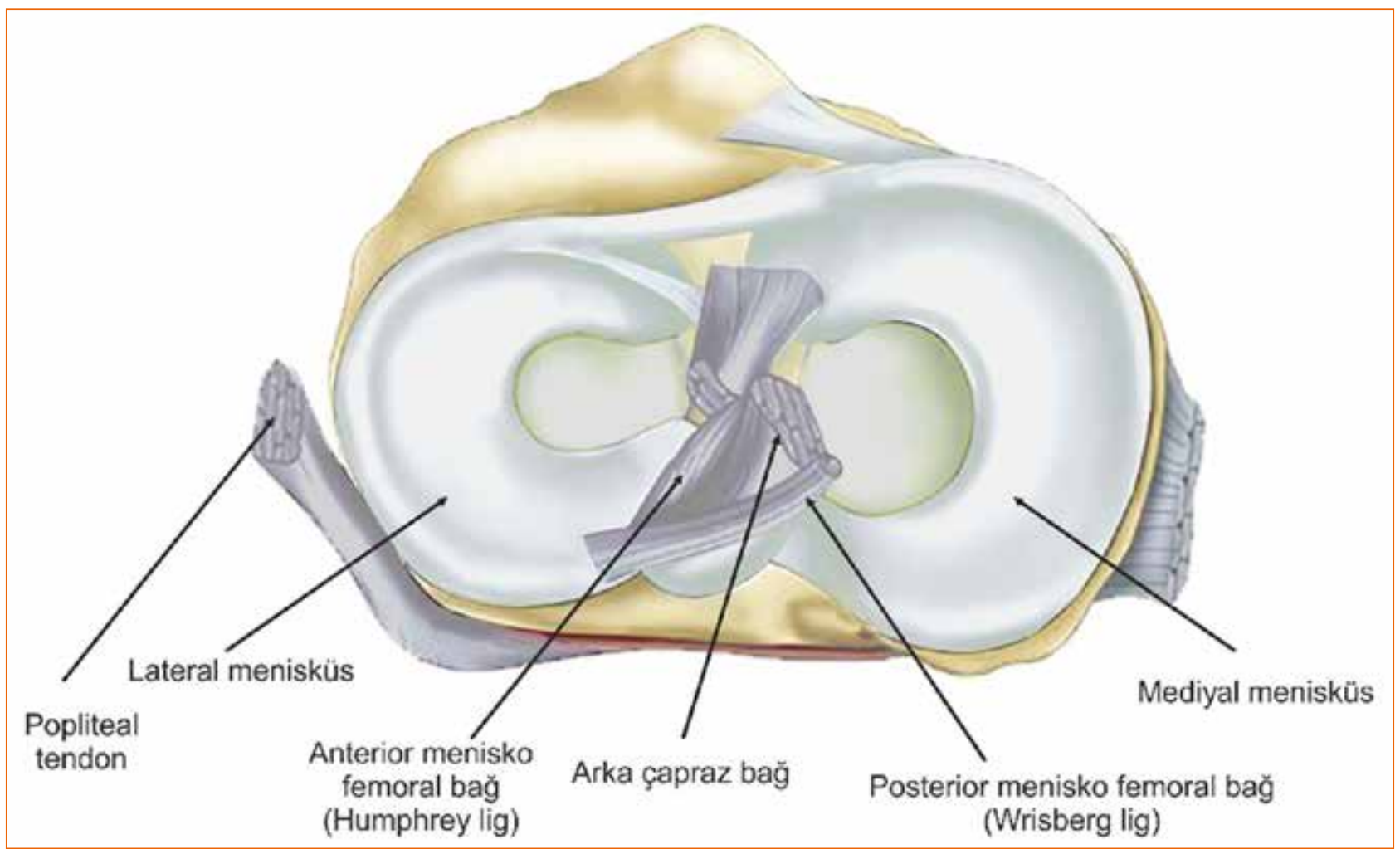

Şekil 5. Lateral menisküs arka boynuzdan çıkan anterior (Humphrey) ve posterior (Wrisberg). meniskofemoral bağlar posteriorda femur mediyal kondiline yapışır. Posterolateralde lateral menisküs komşuluğunda popliteus tendonu bulunur.

hayati öneme sahiptir. Menisküs kök yaralanmalarının anatomik onarımında, anterior ve posterior kök anatomisi ayrıntılı olarak bilinmelidir. Anatominin bilinmesi, sadece menisküs kök lezyonlarının onarımında değil, aynı zamanda menisküs transplantasyonu uygulanacak hastalar için de gereklidir. ${ }^{[24,30]}$

Mediyal menisküs anterior kökün merkezi, tüberositas tibianın mediyal ve proksimalinde, mediyal tibial eminensiya apeksinin anteriorunda bulunur. ${ }^{[22]}$ Anteromediyal kök yaklaşık $110,4 \mathrm{~mm}^{2}$ 'dir ve bunun 56,3 mm $^{2}$ 'sini santral bağlantılar oluşturur. ${ }^{[22]}$ Mediyal menisküs posterior kökün merkezi, mediyal tibial eminensiya apeksinin posteriorunda ve lateralinde, AÇB tibial yapışma bölgesinin anteromediyalinde, lateral menisküs arka kökünün posteriorunda yer alır (Şekil 2). ${ }^{[24]}$ Arka kök yapışma alanı 30,4 mm²'dir. ${ }^{[24]}$

Lateral menisküs arka kökün merkezi, ÖÇB anterolateralinde, lateral tibial eminensiya apeksinin anteromediyalinde bulunur. ${ }^{[22]}$ Anterolateral kök yaklaşık 140,7 mm²'dir ve 88,9 mm²'lik kısmı ÖÇB ile birleşmektedir. ${ }^{[22]}$ Lateral menisküs posterior kökü, lateral tibial eminensiya apeksinin posteromediyalinde, $A C ̧ B$ tibial yapışma bölgesinin anteriorunda ve mediyal menisküs posterior kökün anterolateralinde bulunur. Arka kök yapışma alanı 39,2 mm$^{2}$ 'dir. Ana liflerinin yanı sıra bazı lifleri mediyal tibial eminensiya posterolateraline yapışır (Şekil 2). ${ }^{24]}$

\section{Vasküler Anatomi}

Çocuklarda, kan damarları ve lenfatikler bir yaş dolana kadar menisküsün tamamında bulunur. Çocuk yürümeye başlayıp menisküslere yük binmeye başladıktan sonra, 18 ay civarında kanlanan menisküs bölgesi periferik \%25-33'lük kısmına geriler. ${ }^{111]}$ Merkezdeki fibrokıkırdak bölge avasküler kalır. Diğer bir avasküler bölge, popliteus komşuluğunda lateral menisküs posterolateralidir. ${ }^{[31]}$ Elli yaş üstü kişilerde, kan damarları ve lenf damarlarının oranı menisküsün \%10-33'üne geriler. ${ }^{[11]}$ Anterior ve posterior boynuzlarda zengin kanlanma mevcuttur. Bu durum, boynuz bölgelerinde sinirlerin beslenmesi için gereklidir. ${ }^{[32]}$

Erişkinlerde menisküs beslenmesi, periferik bölgede kan damarlarıla, merkezi bölgede ise sinoviyal sividan diffüzyon yoluyla olur. Sinoviyal sıvidan diffüzyon yoluyla beslenme olabilmesi için, menisküslerde vücut ağırlığı ve kas kasılmaları sonucunda oluşan yüklenme 


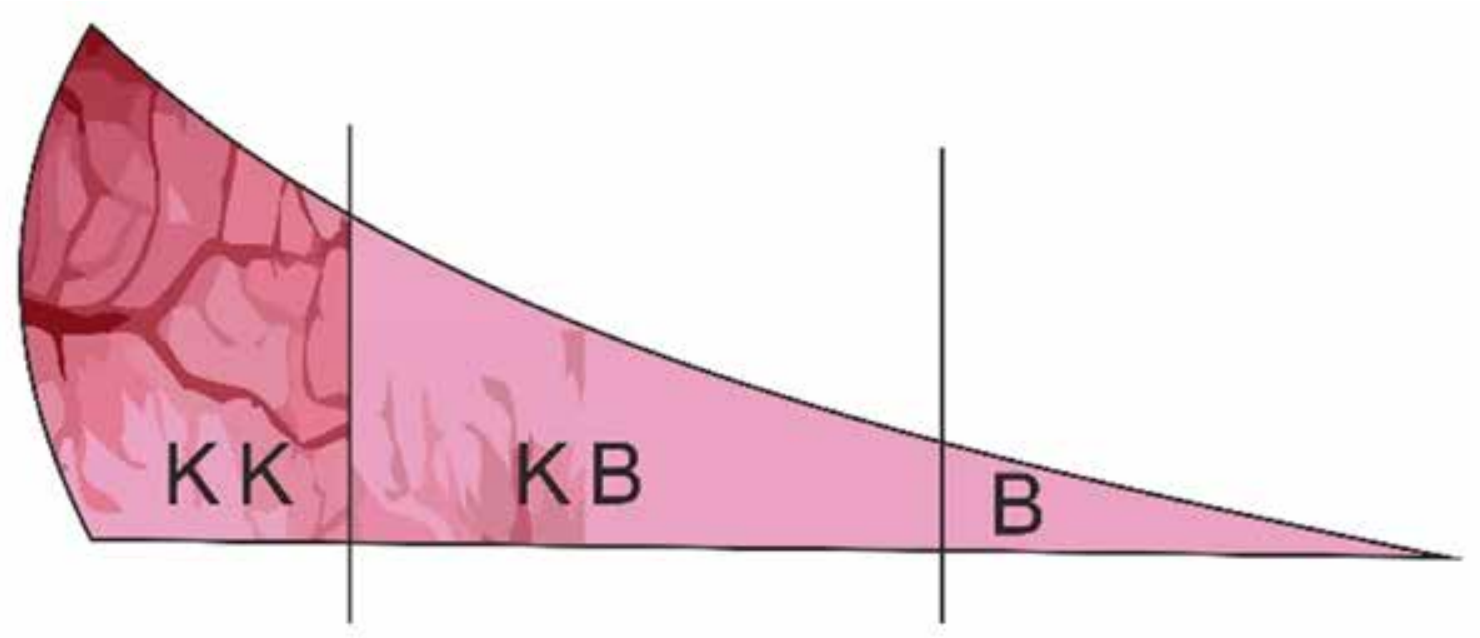

Şekil 6. Menisküs kanlanması; periferde damarlardan zengin bölge kırmızı-kırmızı (KK), kısmi kanlanan bölge kırmızı-beyaz (KB) ve avasküler bölge beyaz-beyaz (BB).

ve aralıklı gevşeme gereklidir. Yürümeye başlamamış bebeklerde bu yüklenmeler olmaz, ancak bu yaştaki bebeklerde tüm menisküs vaskülarizedir. ${ }^{[11]}$

Menisküsler nispeten avasküler yapılardır. Menisküs üçgen yapıdaki kesitleri incelendiğinde üç bölgeye ayrılır. Kırmızı-kırmızı (KK) bölge tam kanlanan en periferdeki bölgedir. Kırmızı-beyaz (KB) bölge damarlı bölge sınırındaki kısmi kanlanan bölgedir. Beyazbeyaz (BB) bölge ise damarlanma olmayan merkezi bölgedir (Şekil 6). ${ }^{[33]}$

Superior ve inferior mediyal ve lateral genikülat arterler, kapsül ve sinovyanın beslenmesini sağlar. Bu damarlar, kapsül ve sinovya içerisinde perimeniskal pleksus oluşturarak menisküslerde boynuz ve periferik bölgeleri besler. Orta genikülat arterin mediyal ve lateral dalları da, anterior ve posterior boynuzları örten sinoviyal dokular aracılığıla menisküs beslenmesine katkıda bulunur. ${ }^{[34]}$

\section{Nöral Anatomi}

Menisküs periferik 2/3'lük kısmında ve boynuzlarda, serbest sinir uçları ve Ruffini, Paccini ve Golgi tendon organı olmak üzere üç farklı mekanoreseptör bulunur. iç 1/3'lük kısımda innervasyon bulunmaz. ${ }^{[32]}$ Bu durumun biyomekanik bir ihtiyaçtan kaynaklandığı belirtilmektedir. Zira, menisküs periferine uygulanacak basıncın algılanması ve eklemde buna göre bir düzeltme ve adaptasyon gerekliyken, menisküs santral bölgeye gelen basınçlarda böyle bir ihtiyaç yoktur. ${ }^{[35]}$ Anterior ve posterior boynuzlarda gövde kısmına oranla daha fazla sinir ve damar bulunur. Periferik 1/3'lük bölgede orta $1 / 3^{\prime}$ lük bölüme göre daha fazla sinir bulunur. Posterior boynuzlarda anterior boynuzlara oranla daha fazla innervasyon bulunur. Bu durumun posterior boynuzun daha fazla yüklere maruz kalması nedeniyle olabileceği düşünülmektedir. ${ }^{[35]}$

Menisküste yer alan mekanoreseptörler aracılığıyla gerilim ve kompresyon kuvetleri algılanır ve afferent sinirlerle santral sinir sistemine iletilir. Santral sinir sisteminden efferent sinirlerle taşınan motor uyarılar ise diz çevresindeki kasları etkileyerek, kas tonusunda değişiklikler ve refleks kas kasılmalarla motor kontrolü sağlar. ${ }^{[36]}$ Menisküste yer alan afferent lifler, dizin pozisyonu, hareket yönü, hareket hızı ve ivmesi gibi bilgileri de santral sinir sistemine iletir. Menisküs yaralanması sonrasında menisküs propriyoseptif özelliği azalmakta, bu durumda diz ekleminin pozisyon almasını bozmakta, instabiliteye neden olmaktadır. Sonuç olarak, görülen tekrarlayan mikrotravmalar osteoartrite sebep olmaktadır. ${ }^{[37]}$

\section{BIYOMEKANIK VE FONKSIYYNEL ÖZELLIKLER}

Menisküslerin; yük iletimi, şok emilimi, stabilite, beslenme, eklem lubrikasyonu ve propriyosepsiyonu gibi önemli görevleri vardır; dizde eklem uyumunu ve temas alanını arttırarak temas streslerinin azalmasını sağlar. ${ }^{[3]}$

\section{Yük İletimi}

Illk olarak Fairbank, menisküslerin yük taşıma fonksiyonunu ve menisektomili dizlerde osteoartrit gelişimini tanımlamıştır. ${ }^{[2]}$ Lateral kompartmana 
etkiyen yüklerin \%70'i, mediyal kompartmana etkiyen kuvvetlerin ise \%50'si menisküsler tarafından iletilir. Ekstansiyondaki dize etkiyen kompresif kuvvetlerin \%40-60'ı posterior boynuzlara etkimekte, fleksiyonda bu oran \%90'lara çıkmaktadır. ${ }^{[3]}$ Yük taşıma sırasında ekleme gelen vertikal kuvvetler, kollajen lifleri aracılığıyla dairesel gerilme kuvvetlerine dönüşür. Yapılan mekanik çalışmalarda, menisküs sağlamken diz ekleminde yüklerin iyi bir dağılım gösterdiği, menisküs kaybını takiben ise eklem temas alanlarının azalmasına bağlı olarak temas streslerinde belirgin artışlar olduğu gösterilmiştir. ${ }^{[4]}$ Total lateral menisektomi sonrasında, eklem temas alanının \%40-50 azaldığı ve buna bağlı olarak lateral kompartmanda temas streslerinin \%200-300 oranında arttığı, total mediyal menisektomi sonrasında ise temas alanının \%50-70 azaldığı ve temas streslerinde \%100 artış olduğu gösterilmiştir. ${ }^{[38]}$

\section{Şok Emilimi}

Viskoelastik yapısı nedeniyle, dize gelen titreşimler menisküsler tarafından $\% 20$ oranında emilir. ${ }^{[39]}$

\section{Stabilite}

Sağlam menisküs, diz hareketlerini tüm yönlerde kısıtlayarak aşırı hareketlerin oluşmasını önler ve dizde stabilite sağlar; mediyal menisküsün daha sıkı bir şekilde tibiaya yapışması nedeniyle, dizde anterior stabiliteye katkı yapar. Ön çapraz bağı kesilmiş ve ön çapraz bağı sağlam dizlerde yapılan mediyal menisektomi sonrasında, menisektomili dizlerde anterior instabilitenin artış gösterdiği, lateral menisektomi sonrasında ise anterior instabilitede artış olmadığı gösterilmiştir. Lateral menisektomi sonrasında, translasyon, rotasyon ve pivot şiftin arttığı gösterilmiştir. ${ }^{[3]}$

\section{Eklem Lubrikasyonu ve Beslenme}

Menisküs, eklem lubrikasyonu ve beslenmesine de katkı yapar. Menisektomi sonrasında diz eklemi sürtünme katsayısının \%20 artış gösterdiği bildirilmiştir. Etkin mekanizma tam olarak bilinmemekle birlikte, menisküse gelen yükler sonrasında, menisküsten eklem içerisine sinoviyal sıvı geçişi olduğu ve bu sıvının lubrikasyonu ve beslenmeyi sağladığı düşünülmektedir. Bahsedilen sıvı transferi, menisküs kanlanmasının olduğu bölgelere yakın mikrokanal sistemi ve kan damarları vasıtasıyla olmaktadır. ${ }^{[4]}$

\section{Propriyosepsiyon}

Menisküsler, anterior ve posterior boynuzlar aracilığıyla propriyoseptif özellikler de gösterir. Hızlı adapte olan mekanoreseptörler (Pacini) eklem hareketlerinin algılanmasında, yavaş adapte olan reseptörler ise (Ruffini, Golgi tendon organı) eklem pozisyonu algılanmasında etkindir. Bu reseptörler orta ve dış menisküs bölgelerinde bulunur. ${ }^{[3]}$

\section{SONUÇ}

Menisküsler, bir zamanlar belirtildiği gibi önemsiz değil, aksine diz eklemi için son derece önemli yapılardır ve diz eklemi biyomekaniğinde önemli görevleri vardır. Bunlar, şok emilimi, stabilite, lubrikasyon, beslenme ve propriyosepsiyon gibi farklı görevlerdir. Kendine özgü ve kısmen avasküler-anöral bir yapıya sahiptir. Ön ve arka kök yapıları menisküs stabilitesinde çok önemli yapılardır. Menisküs yaralanmaları sonrasında, geçmişte yapılan uygulamaların aksine, menisküs korunmalı ve anatomik olarak onarılmalıdır. Bu nedenle, menisküslerin ayrıntılı anatomilerinin bilinmesi, menisküs yaralanmalarının tedavisinde hayati önemdedir.

\section{KAYNAKLAR}

1. Sutton JB. Ligaments: Their Nature and Morphology, 2nd ed. London: H.K.Lewis; 1897. 114 p.

2. Fairbank TJ. Knee joint changes after meniscectomy. J Bone Joint Surg Br 1948;30-B(4):664-70. Crossref

3. Fox AJS, Wanivenhaus F, Burge AJ, Warren RF, Rodeo SA. The Human Meniscus: A Review of Anatomy, Function, Injury, and Advances in Treatment. Clin Anat 2015;28(2):269-87. Crossref

4. Fox AJS, Bedi A, Rodeo SA. The basic science of human knee menisci: structure, composition, and function. Sports Health 2012;4(4):340-51. Crossref

5. Tardieu C, Dupont JY. The origin of femoral trochlear dysplasia: comparative anatomy, evolution, and growth of the patellofemoral joint. Rev Chir Orthop Reparatrice Appar Mot 2001;87(4):373-83.

6. Tardieu C. Ontogeny and phylogeny of femoro-tibial characters in humans and hominid fossils: functional influence and genetic determinism. Am J Phys Anthropol 1999;110(3):365-77. Crossref

7. Villegas DF, Hansen TA, Liu DF, Donahue TLH. A quantitative study of the microstructure and biochemistry of the medial meniscal horn attachments. Ann Biomed Eng 2008;36(1):123-31. Crossref

8. Messner K, Gao J. The menisci of the knee joint. Anatomical and functional characteristics, and a rationale for clinical treatment. J Anat 1998;193(Pt 2):161-78. Crossref

9. Gardner E, O'Rahilly R. The early development of the knee joint in staged human embryos. J Anat 1968;102(Pt 2):289-99.

10. Clark CR, Ogden JA. Development of the Menisci of the Human Knee Joint Morphological Changes and Their Potential Role in Childhood Meniscal Injury. J Bone Joint Surg Am 1983;65(4):538-47. Crossref

11. Petersen W, Tillmann B. Age-related blood and lymph supply of the knee menisci: A cadaver study. Acta Orthop Scand 1995;66(4):308-12. Crossref 
12. Herwig J, Egner E, Buddecke E. Chemical Changes of Human Knee Joint Menisci in Various Stages of Degeneration. Ann Rheum Dis 1984;43(4):635-40. Crossref

13. Cheung HS. Distribution of Type I, II, III, and V in the Pepsin Solubilized Collagens in Bovine Menisci. Connect Tissue Res 1987;16(4):343-56. Crossref

14. Mcdevitt CA, Webber RJ. The Ultrastructure and Biochemistry of Meniscal Cartilage. Clin Orthop Relat Res 1990;(252):818. Crossref

15. Tandoğan NR. The meniscus: biomechanics, kinematics and function. Acta Orthop Traumatol Turc 1997;31:397-401.

16. Verdonk PC, Forsyth RG, Wang J, Almqvist KF, Verdonk R, Veys EM, Verbruggen G. Characterisation of human knee meniscus cell phenotype. Osteoarthritis Cartilage 2005;13(7):548-60. Crossref

17. Van der Bracht $H$, Verdonk R, Verbruggen G, Elewaut D, Verdonk P. Cell based meniscus tissue engineering. In: Ashammakhi N, Reis RL, Chiellini E, editors. Topics in Tissue Engineering, 2007.

18. Bezerra FS, Alves JN, Silva MAS, Trajano ETL, Ferreira TA, Vasconcellos HA, Valença SS. Quantitative and descriptive analysis of the meniscotibial ligament in human corpses. Braz J Morphol Sci 2007;24(4):211-3.

19. Rath E, Richmond JC. The menisci: basic science and advances in treatment. Br J Sports Med 2000;34(4):252-7. Crossref

20. Smigielski R, Becker R, Zdanowicz U, Ciszek B. Medial meniscus anatomy -from basic science to treatment. Knee Surg Sports Traumatol Arthrosc 2015;23(1):8-14. Crossref

21. Berlet GC, Fowler PJ. The anterior horn of the medical meniscus. An anatomic study of its insertion. Am J Sports Med 1998;26(4):540-3. Crossref

22. LaPrade CM, Ellman MB, Rasmussen MT, James EW, Wijdicks CA, Engebretsen L, LaPrade RF. Anatomy of the Anterior Root Attachments of the Medial and Lateral Menisci. A Quantitative Analysis. Am J Sport Med 2014;42(10):238692. Crossref

23. Fenn S, Datir A, Saifuddin A. Synovial recesses of the knee: MR imaging review of anatomical and pathological features. Skeletal Radiol 2009;38(4):317-28. Crossref

24. Johannsen AM, Civitarese DM, Padalecki JR, Goldsmith MT, Wijdicks CA, LaPrade RF. Qualitative and quantitative anatomic analysis of the posterior root attachments of the medial and lateral menisci. Am J Sports Med 2012;40(10):2342-7. Crossref
25. Last RJ. The popliteus muscle and the lateral meniscus. J Bone Joint Surg Br 1950;32-B(1):93-9. Crossref

26. Zivanovic $S$. Menisco-meniscal ligaments of the human knee joint. Anat Anz 1974;135(1-2):35-42.

27. Masouros SD, McDermott ID, Amis AA, Bull AM. Biomechanics of the meniscus-meniscal ligament construct of the knee. Knee Surg Sports Traumatol Arthrosc 2008;16(12):1121-32. Crossref

28. Allaire R, Muriuki M, Gilbertson L, Harner CD. Biomechanical consequences of a tear of the posterior root of the medial meniscus. Similar to total meniscectomy. J Bone Joint Surg Am 2008;90(9):1922-31. Crossref

29. Marzo JM, Kumar BA. Primary repair of medial meniscal avulsions: 2 case studies. Am J Sports Med 2007;35(8):13803. Crossref

30. Packer JD, Rodeo SA. Meniscal allograft transplantation. Clin Sports Med 2009;28(2):259-83. Crossref

31. Petrosini AV, Sherman $\mathrm{OH}$. A historical perspective on meniscal repair. Clin Sports Med 1996;15(3):445-53.

32. Gray JC. Neural and vascular anatomy of the menisci of the human knee. J Orthop Sports Phys Ther 1999;29(1):23-30. Crossref

33. Arnoczky SP, Warren RF. Microvasculature of the human meniscus. Am J Sports Med 1982;10(2):90-5. Crossref

34. Renström P, Johnson RJ. Anatomy and biomechanics of the menisci. Clin Sports Med 1990;9(3):523-38.

35. Zimny ML, Albright DJ, Dabezies E. Mechanoreceptors in the human medial meniscus. Acta Anat (Basel)1988;133(1):35-40. Crossref

36. Nyland J, Brosky T, Currier D, Nitz A, Caborn D. Review of the afferent neural system of the knee and its contribution to motor learning. J Orthop Sports Phys Ther 1994;19(1):2-11. Crossref

37. Jerosch J, Prymka M. Proprioception and joint stability. Knee Surg Sports Traumatol Arthrosc 1996;4(3):171-9. Crossref

38. Fukubayashi $\mathrm{T}$, Kurosawa $\mathrm{H}$. The contact area and pressure distribution pattern of the knee: a study of normal and osteoarthritic knee joints. Acta Orthop Scand 1980;51(16):871-9. Crossref

39. Voloshin AS, Wosk J. Shock absorption of meniscectomized and painful knees: a comparative in vivo study. J Biomed Eng 1983;5(2):157-61. Crossref 